\title{
Correction to: Comprehensive genetic analyses using targeted next-generation sequencing and genotype-phenotype correlations in 53 Japanese patients with osteogenesis imperfecta
}

\author{
Y. Ohata ${ }^{1}$ - S. Takeyari $^{1}$ • Y. Nakano ${ }^{1} \cdot$ T. Kitaoka ${ }^{1} \cdot$ H. Nakayama ${ }^{1,2} \cdot$ V. Bizaoui $^{1,3} \cdot$ K. Yamamoto $^{1,4} \cdot$ K. Miyata $^{1}$. \\ K. Yamamoto ${ }^{1,5} \cdot$ M. Fujiwara $^{1,6} \cdot$ T. Kubota $^{1} \cdot$ T. Michigami $^{7} \cdot$ K. Yamamoto $^{8} \cdot$ T. Yamamoto $^{9} \cdot$ N. Namba ${ }^{1,10}$. \\ K. Ebina ${ }^{11} \cdot$ H. Yoshikawa ${ }^{12} \cdot K$. Ozono ${ }^{1}$
}

Published online: 3 April 2020

(C) The Author(s) 2020

Correction to: Osteoporosis International (2019) 30:2333-2342, https://doi.org/10.1007/s00198-019-05076-6

The article, Comprehensive genetic analyses using targeted next-generation sequencing and genotype-phenotype correlations in 53 Japanese patients with osteogenesis imperfecta, written by Y. Ohata, S. Takeyari, Y. Nakano, T. Kitaoka, H. Nakayama, V. Bizaoui, K. Yamamoto, K. Miyata, K. Yamamoto, M. Fujiwara, T. Kubotal, T. Michigami, K. Yamamoto, T. Yamamoto, N. Namba, K. Ebina, H. Yoshikawa, and K. Ozono was originally published Online First without Open Access. After publication in volume [30], issue [11], pages [2333-2342], the author decided to opt for Open Choice and to make the article an Open Access publication. Therefore, the copyright of the article has been changed to (C) The Author(s) [2019] and the article is forthwith distributed under the terms of a Creative Commons Attribution-NonCommercial 4.0 International License (https://creativecommons.org/licenses/bync/4.0/), which permits any non-commercial use, sharing,

The online version of the original article can be found at https://doi.org/ 10.1007/s00198-019-05076-6

K. Ozono

keioz@ped.med.osaka-u.ac.jp

1 Department of Pediatrics, Osaka University Graduate School of Medicine, Suita, Japan

2 The Japan Environment and Children's Study, Osaka Unit Center, Suita, Japan

3 Department of Medical Genetics, Reference Center for Skeletal Dysplasia, Hôpital Necker - Enfants Malades, Paris, France

4 Department of Statistical Genetics, Osaka University Graduate School of Medicine, Suita, Japan

5 Department of Pediatrics, National Hospital Organization Osaka National Hospital, Osaka, Japan adaptation, distribution, and reproduction in any medium or format, as long as you give appropriate credit to the original author(s) and the source, provide a link to the Creative Commons license, and indicate if changes were made.

The original article has been corrected.

Open Access This article is licensed under a Creative Commons Attribution-NonCommercial 4.0 International License, which permits any non-commercial use, sharing, adaptation, distribution and reproduction in any medium or format, as long as you give appropriate credit to the original author(s) and the source, provide a link to the Creative Commons licence, and indicate if changes were made. The images or other third party material in this article are included in the article's Creative Commons licence, unless indicated otherwise in a credit line to the material. If material is not included in the article's Creative Commons licence and your intended use is not permitted by statutory regulation or exceeds the permitted use, you will need to obtain permission directly from the

6 The First Department of Oral and Maxillofacial Surgery, Osaka University Graduate School of Dentistry, Suita, Japan

7 Department of Bone and Mineral Research, Osaka Women's and Children's Hospital, Izumi, Japan

8 Department of Pediatric Nephrology and Metabolism, Osaka Women's and Children's Hospital, Izumi, Japan

9 Department of Pediatrics, Minoh City Hospital, Minoh, Japan

10 Department of Pediatrics, Osaka Hospital, Japan Community Healthcare Organization (JCHO), Osaka, Japan

11 Department of Musculoskeletal Regenerative Medicine, Osaka University Graduate School of Medicine, Suita, Japan

12 Department of Orthopaedic Surgery, Osaka University Graduate School of Medicine, Suita, Japan 